\title{
Increasing Writing Skills Study Result Through the Experience Write a Diary In Primary School
}

\author{
Cici Evianti Alafiyah \\ SDN 05 Bantarbolang \\ alafiyah08@gmail.com
}

\section{Article History}

received 3/12/2020

\begin{abstract}
Classroom action research is conducted to address learning problems that occur in the classroom. In addition, classroom action research is also used to improve the quality of learning so that student learning outcomes can increase. This classroom action research was conducted on sixth grade students at the State Elementary School 05 Bantarbolang Pemalang. Where this classroom action research aims to improve student learning outcomes in writing skills on fiction and non-fiction text material by using the experience of writing a diary. From the results of research conducted in two cycles showed an increase. Learning outcomes in the first cycle showed a class average of 74.88 while classical learning completeness was $76.92 \%$. The learning outcomes in the second cycle showed the class average value of 87.07 while the classical learning completeness was $100 \%$. This proves that the use of the experience of writing a diary can improve the learning outcomes of students' writing skills. Teachers can use the experience of writing a diary to improve students' writing skills.
\end{abstract}

Keywords: writing skill, diary, learning outcomes

\begin{abstract}
Abstrak
Penelitian Tindakan kelas dilakukan untuk mengatasi permasalah pembelajaran yang terjadi di kelas. Selain itu penelitian tidakan kelas juga digunakan untuk meningkatkan kulaitas pembelajaran sehingga hasil belajar peserta didik dapat meningkat. Penelitian Tindakan kelas ini dilaksanakan pada peserta didik kelas VI di Sekolah dasar Negeri 05 Bantarbolang Pemalang. Dimana penelitian Tindakan kelas ini bertujuan meningkatkan hasil belajar peserta didik dalam ketrampilan menulis pada materi teks fiksi dan non fiksi dengan menggunaka pengalaman menulis buku catatan harian. Dari hasil penelitian yang dilakukan sebanyak dua siklus menunjukkan adanya peningkatan. Hasil belajar pada siklus I menunjakan rata-rata kelas sebesar 74,88 sedangkan ketuntasan belajar klasikal sebesar 76,92 \%. Hasil belajar pada siklus II menunjukkan nilai rata-rata kelas sebesar 87,07 sedangkan ketuntasan belajar klasikal adalah $100 \%$. Hal ini membuktikan bahwa penggunaan pengalaman menulis buku catatan harian dapat meningkatkan hasil belajar ketrampilan menulis peserta didik. Guru dapat menggunakan pengalaman menulis buku catatan harian untuk meningkatkan ketrampilan menulis peserta didik.
\end{abstract}

Kata kunci: Ketrampilan menulis, buku catatan harian, hasil belajar

Social, Humanities, and Education Studies (SHEs): Conference Series https://jurnal.uns.ac.id/shes 


\section{PENDAHULUAN}

Menurut Undang-Undang Nomor 20 Tahun 2003 pada Bab I pasal 1 menjelaskan kurikulum merupakan seperangkat rencana dan pengaturan mengenai tujuan, isi, dan bahan pelajaran serta cara yang digunakan sebagai pedoman penyelenggaraan kegiatan pembelajaran untuk mencapai tujuan pendidikan tertentu. Dari penjelasan di atas dapat disimpulkan bahwa kurikulum berisi bahan pelajaran yang digunakan sebagai pedoman dalam kegiatan pembelajaran untuk mencapai tujuan pendidikan.

Kurikulum 2013 merupakan kurikulum yang bertujuan mempersiapkan manusia Indonesia sebagai pribadi yang beriman, produktif, kreatif dan inovatif serta mampu memberikan kontribusi bagi kehidupan bermayarakat, berbangsa dan bernegara serta peradaban dunia. Kurikulum 2013 bertujuan membuat peserta didik untuk lebih bisa berpikir kreatif, inovatif, kritis dan cepat tanggap dalam menanggapi masalah. Kurikulum 2013 terdapat beberapa unsur-unsur kehidupan bermasyarakat, berbangsa dan bernegara serta unsur keagamaan untuk membentuk peserta didik yang berkarakter yang dimasukan didalamnya.

Pada kurikulum 2013, pembelajaran Bahasa Indonesia merupakan pembelajaran yang digunakan sebagai sarana mengembangkan ketrampilan menalar. Pembelajaran Bahasa Indonesia pada kurikulum 2013 berorientasi pada pembelajaran berbasis teks. Pembelajaran berbasis teks bertujuan untuk mengembangkan kemampuan berekspresi peserta didik terhadap dirinya dalam bentuk tulisan. Sehingga ketrampilan menulis sangat diperlukan dalam tercapainya tujuan pembelajaran ini.

Keterampilan menulis merupakan suatu keterampilan berbahasa yang dipergunakan untuk berkomunikasi secara tidak langsung. Menulis juga merupakan suatu kegiatan yang produktif dan efektif (Tarigan 2008: 3). Menulis merupakan keterampilan berbahasa yang bersifat kompleks dan cenderung lebih sulit dibandingkan dengan keterampilan berbahasa yang lain. Berkaitan dengan hal tersebut perlu adanya pembelajaran yang lebih efektif dalam pembelajaran menulis di sekolah dasar.

Pembelajaran menulis di sekolah dasar dibedakan menjadi dua tingkatan yaitu menulis permulaan dan menulis lanjut (Kristiantari 2004: 106). Pada tingkat menulis permulaan kegiatan dan latihan menulis lebih bersifat mekanistik artinya menulis permulaan lebih mengutamakan pada segi teknik menulis dari pada isi tulisan tersebut. Sasaran menulis permulaan adalah siswa kelas rendah yaitu siswa kelas I sampai dengan kelas III. Sedangkan menulis lanjutan lebih menekankan pada perwujudan ungkapan ide, pikiran, gagasan yang tertuang dalam isi tulisan berupa lambanglambang bunyi secara tertulis. Sasaran menulis lanjutan adalah siswa kelas tinggi yaitu antara siswa kelas IV sampai dengan kelas VI. Apabila tujuan pembelajaran menulis di sekolah dasar tercapai maka pembentukan dan pengembangan kemampuan menulis di tingkat selanjutnya diharapkan dapat tercapai.

Media pembelajaran digunakan untuk mempermudah siswa dalam belajar. Belajar merupakan suatu proses perubahan tingkah laku sebagai hasil dari pengalaman. Untuk itu, guru perlu memahami tingkat pengalaman siswa untuk mengetahui media apa yang tepat untuk digunakan. Menurut A. H Sulaeman (1981) dalam Subana dan Sunarti (2011: 292) menggolongkan pengalaman manusia ke dalam beberapa tingkatan yaitu (1) pengalaman nyata merupakan pengalaman langsung yang mengikutsertakan semua indra dan akal, (2) pengganti pengalaman nyata adalah pengalaman yang dapat menjembatani antara pengalaman nyata dengan kata-kata, maksudnya menggatikan pengalaman nyata yang tidak dapat dihayati tanpa disertai alat dan kata-kata dengan pengalaman yang mendekati pengalaman nyata, (3) pengalaman verbal artinya keterangan berupa kata-kata belaka, yaitu sesuatu yang didengar atau dibaca tidak selalu mudah dimengerti. Untuk mempermudah dalam penentuan media, maka media dibagi kedalam beberapa jenis.

Penggunaan media pembelajaran menulis yang digunakan di dalam kelas hanya membantu siswa dalam memahami teori tentang menulis. Teori menulis hanya 
membantu siswa untuk tahu bagaimana menulis tanpa melatih keterampilan menulis. Hal ini membuat siswa merasa kesulitan dalam menuangkan gagasan dalam sebuah kalimat sehingga siswa belum terbiasa dan terlatih dalam menuangkan gagasan mereka.

Selain media yang digunakan dalam pembelajaran menulis di kelas perlu adanya media lain. Media yang bisa digunakan untuk melatih keterampilan menulis siswa agar lebih terlatih dan penggunaannya tidak terbatasi oleh waktu.. Menurut Aveus Har (2011: 3-4) buku catatan harian atau jurnal merupakan suatu buku yang digunakan untuk menuliskan rekaman peristiwa yang bisa berupa perasaan, pendapat, atau pemikiran tentang sesuatu. Buku catatan harian merupakan media yang tepat digunakan untuk melatih keterampilan menulis siswa terutama keterampilan menulis narasi. Hal ini dikarenakan media buku catatan harian selain penggunaannya tidak dibatasi oleh waktu dan dapat digunakan saat di rumah maupun di sekolah. Buku catatan harian biasanya digunakan untuk menuliskan pengalaman pribadi seseorang. Pengalaman pribadi yang ditulis dalam buku catatan harian merupakan salah satu bentuk karangan narasi.

Penelitian penggunaan media buku catatan harian dalam pembelajaran menulis pernah dilakukan oleh Dety Amalia Karlina pada tahun 2011. Dalam tesisnya yang berjudul Pengaruh Pembelajaran Menulis dengan Menggunakan Buku Catatan Harian terhadap Kebiasan Menulis dan Keterampilaan Menulis Siswa di Sekolah Dasar. Hasil penelitian yang diperoleh menunjukkan adanya peningkatan hasil belajar menulis siswa pada kelas eksperimen yaitu sebesar $37,94 \%$ dari hasil tes awal, sedangkan untuk kebiasaan menulis siswa meningkat sebesar $16,89 \%$ dari hasil tes awal . Dari hasil penelitian tersebut dapat disimpulkan bahwa media buku catatan harian dapat meningkatkan hasil belajar keterampilan menulis siswa.

Berdasarkan hasil refleksi pembelajaran yang dilakukan guru. Masih banyak peserta didik dalam membuat karangan narasi mendapat nilai dibawah KKM yaitu 70 . Guru belum memanfaatkan media ataupun strategi pembelajaran yang maksimal. Selain itu peserta didik juga kesulitan dalam mengungkapkan ide atau gagasan yang akan digunakan untuk memulai membuat sebuah tulisan sehingga peserta didik malas untuk menulis.

Rumusan masalah pada penelitian ini memfokuskan pada peningkatan ketrampilan menulis peserta didik, yaitu (1) Apakah pengalaman peserta didik dalam menulis buku catatan harian dapat meningkatkan ketrampilan menulis peserta didik kelas VI di SD Negeri 05 bantarbolang? (2) Bagaimana meningkatkan ketrampilan menulis siswa melalui pengalaman menulis buku catatan harian pada peserta didik kelas VI SD Negeri 05 Bantarbolang?. Tujuan diadakannya penelitian tidakan kelas adalah untuk memberikan solusi pada permasalah yang muncul dalam pembelajaran di kelas. Tujuan dari penetian Tindakan kelas yang peneliti lakukan adalah untuk meningkatkan hasil belajar menulis pengalaman peserta didik kelas VI di Sekolah Dasar Negeri 05 Bantarbolang Kabupaten Pemalang, Jawa Tengah.

\section{METODE}

Penelitian Tindakan kelas memiliki beberapa siklus . Setiap siklus peneliti melakukan empat Tindakan yaitu: (1) perencanaan; (2) pelaksanaan, (3) observasi; dan (4) refleksi.. Setelah dilakukan refleksi pada siklus I dan masih ditemukan kekurangan, maka peneliti menyempurnakannya dengan melaksanakan siklus II dan seterusnya siklus berulang sampai mendapatkan data penelitian yang diinginkan. Penelitian Tindakan kelas ini dilaksanakan di SD Negeri 05 Bantarbolang yang beralamat pada Jl. Raya Bantarbolang No. 177 Kecamatan Bantarbolang Kabupaten Pemalang, Jawa Tengah. Waktu Penelitian dilakukan pada semester 2 tahun ajaran 2019/2020. Subjek penelitian ini adalah peserta didik kelas VI yang berjumlah 13 peserta didik. Untuk pengumpulan data diperlukan adanya teknik dan instrument pengumpulan data. Beberapa instrumen penelitian yang diperlukan dalam penelitian ini diantaranya adalah kisi-kisi soal tes 
uraian menulis narasi, soal tes uraian menulis narasi, pedoman penilaian menulis narasi dan rubrik dengan skala penilaian. Teknik analisis data yang digunakan adalah analisis hasil belajar siswa dalam menulis teks narasi. Rumus-rumus yang Rumus-rumus yang digunakan untuk menganalisis data hasil belajar siswa yaitu nilai akhir hasil belajar siswa dalam BSNP (2007: 25), nilai rata-rata kelas dalam Sudjana (2010: 109), dan persentase tuntas belajar klasikal dalam Aqib dkk (2010: 41).

\section{HASIL DAN PEMBAHASAN}

Hasil penelitian tindakan kelas yang telah dilakukan adalah sebagai berikut:

1. Siklus I

Data siklus I adalah data dari hasil tes yang berupa nilai hasil belajar peserta didik yang dapat digunakan untuk mengukur kemampuan peserta didik pada pembelajaran keterampilan menulis.

a. Data Hasil Belajar Siklus I

Setelah dilakukan tes membuat tulisan narasi dan dilakukan penilaian. Berikut adalah hasil tes menulis narasi peserta didik pada siklus I setelah dilakukan Tindakan.

Tabel 1. Data Hasil Tes Menulis Siklus I

\begin{tabular}{|c|c|c|c|c|}
\hline No & Kelas Interval & $\mathrm{Xi}$ & $f$ & Xi.f \\
\hline 1 & $57,5-61,5$ & 59,5 & 0 & 0 \\
\hline 2 & $62,5-66,5$ & 64,5 & 1 & 64,5 \\
\hline 3 & $67,5-71,5$ & 69,5 & 3 & 208,5 \\
\hline 4 & $72,5-76,5$ & 74,5 & 2 & 149 \\
\hline 5 & $77,5-81,5$ & 79,5 & 5 & 382,5 \\
\hline \multirow[t]{2}{*}{6} & $82,5-86,5$ & 84,5 & 2 & 169 \\
\hline & Jumlah & & 13 & 973,5 \\
\hline \multicolumn{2}{|c|}{ Nilai rata-rata kelas } & $\begin{array}{l}=\frac{973,5}{13} \\
=74,88\end{array}$ & & \\
\hline & $\begin{aligned} K & =\frac{N(\text { nilai }>70)}{S N} x \\
& =\frac{10}{13} \mathrm{X} 100 \% \\
& =76.92 \%\end{aligned}$ & & & \\
\hline
\end{tabular}

Berdasarkan hasil nilai dari tabel diatas adalah untuk nilai rata-rata kelas adalah 74,88 . Sedangkan untuk ketuntasan belajar klasikal adalah 76,92 \% sedangkan yang belum tuntas terdapat $23,08 \%$. Hasil ketuntasan belajar klasikal dapat dilihat pada diagram yang digambarkan sebagai berikut :

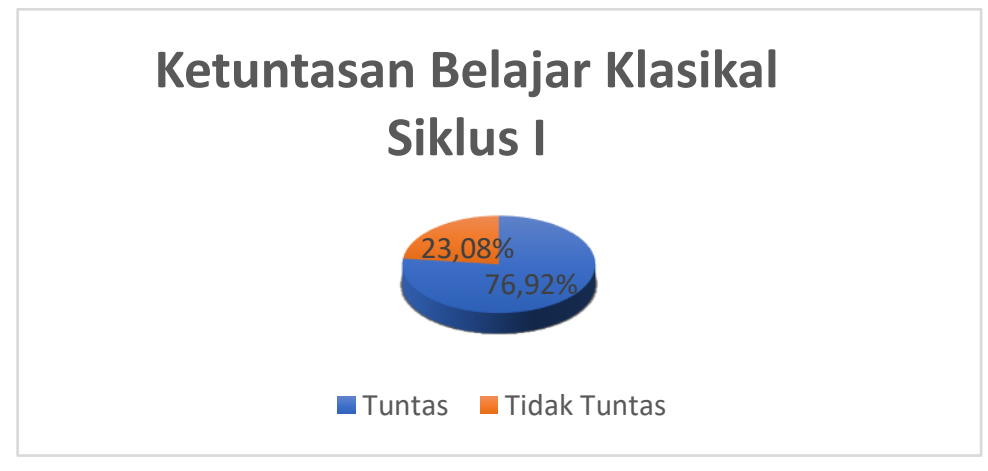

Gambar 1. Hasil Ketuntasan Belajar Klasikal Siklus I 
b. Refleksi

Hasil refleksi pada Siklus I adalah masih terdapat kekurangan dalam pelaksanaan menulis buku catatan harian di rumah. Masih terdapat beberapa peserta didik yang belum mau menulis buku catatan harian dirumah. Guru belum bisa memotivasi peserta didik agar mau mulai menulis buku catatan harian di rumah.

Hasil belajar pada siklus I menunjukkan nilai rata-rata kelas sebesar 74,88 dan presentasi ketuntasan belajar mencapai 76,92\%. Pada hasil tes ini masih terdapat 3 peserta didik yang mendapatkan nilai dibawah KKM yang telah ditentukan yaitu 70.

c. Revisi

Berdasarkan hasil refleksi dari kegiatan siklus I perlu adanya perbaikan yang akan dilakukan pada siklus II. Perbaikan yang akan dilakukan pada siklus II yaitu memberikan motivasi kepada peserta didik agar mau menulis buku catatan harian setiap hari dirumha. Kemudian guru memberkan waktu disetiap akhir pembelajaran untuk membacakan hasil tulisan yang dibuat. Selain itu guru juga bisa memberikan timbal balik terhadap peserta didik yang rajin menulis di buku catatan harian sehingga bisa meningkatkan motivasi peserta didik yang lain agar mau menulis sehingga hasil belajar pada siklus II nanti dapat meningkat.

\section{Siklus II}

Data siklus I adalah data dari hasil tes yang berupa nilai hasil belajar peserta didik yang dapat digunakan untuk mengukur kemampuan peserta didik pada pembelajaran keterampilan menulis.

a. Data Hasil Belajar Siklus I

Setelah dilakukan tes membuat tulisan narasi dan dilakukan penilaian. Berikut adalah hasil tes menulis narasi peserta didik pada siklus I setelah dilakukan Tindakan.

Tabel 2. Data Hasil Tes Menulis Siklus II

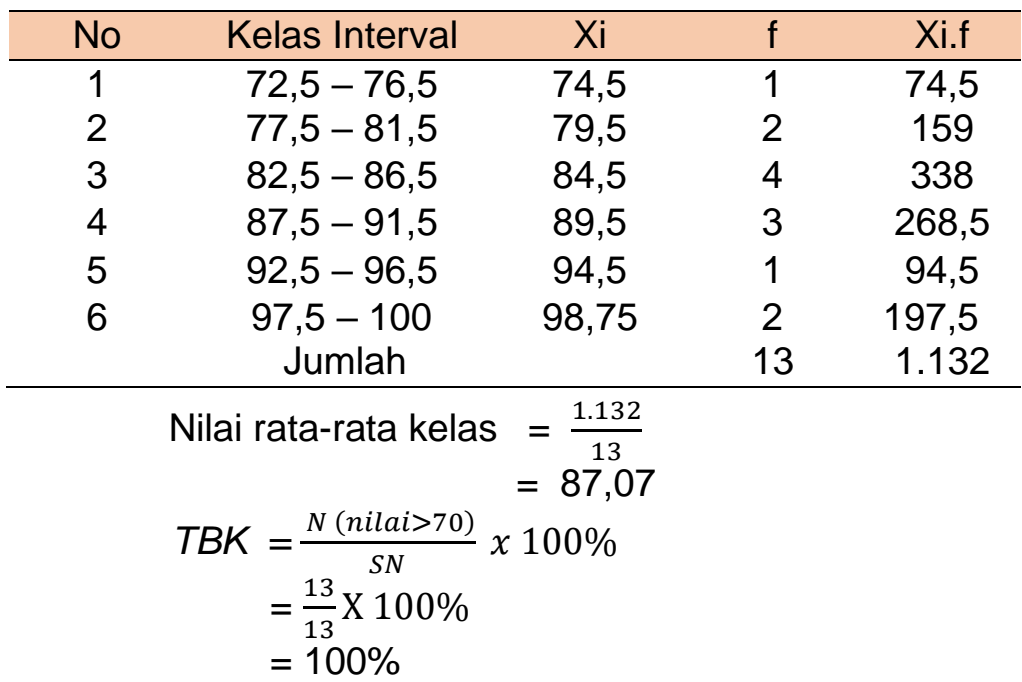

Berdasarkan hasil nilai dari tabel diatas adalah untuk nilai rata-rata kelas adalah 87,07. Sedangkan untuk ketuntasan belajar klasikal adalah $100 \%$. Hasil ketuntasan belajar klasikal dapat dilihat pada gambar 2. 
SHEs: Conference Series 3 (4) (2020) $33-40$

Ketuntasan Belajar Klasikal Siklus II

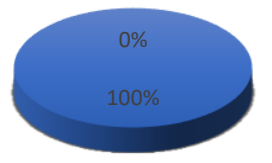

- Tuntas - Tidak Tuntas

b. Refleksi

Gambar 2. Hasil Ketuntasan Belajar Klasikal Siklus II

Hasil refleksi pada Siklus II menunjukkan adanya peningkatan pada hasil belajar siswa. Hasil siklus I menunjukan nilai rata-rata kelas adalah 74,88 sedangkan untuk ketuntasan belajar klasikal adalah 76,92\%. Pada siklus II terdapat peningkatan hasil belajar peserta didik yang ditunjukan pada peningkatan nilai rata-rata kelas yang pada siklus I adalah 74,88 meningkat menjadi 87,07. Sedangkan untuk ketuntasan belajar klasikal juga mengalami peningkatan pada siklus I presentasenya 76,92 \% pada siklus II meningkat menjadi $100 \%$ menandakan peserta didik telah tuntas pada pembelajaran menulis ini. Peningkatan terjadi dikarenakan tindakan yang dilakukan didasarkan pada refleksi tindakan pada siklus I. Dimana guru terus melakukan motivasi kepada peserta didik untuk menulis buku catatan harian di rumah, kemudian guru juga memberikan arahan yang struktur dan jelas sehingga semua peserta didik dapat menulis buku catatan harian di rumah dengan baik. Selain itu pemberian penghargaan kepada peserta didik yang rajin menulis buku catatan harian juga memberikan motivasi kepada peserta didik.

c. Revisi

Berdasarkan hasil data siklus I dan perbaikan tindakan pada siklus II dalam pembelajaran ketrampilan menulis kelas VI materi Teks fiksi di SD Negeri 05 Bantarbolang kabupaten Pemalang. Menunjukkan adanya keefektifan pengalaman menulis buku catatan harian dalam meningkatkan hasil belajar ketrampilan menulis peserta didik. Hal itu ditunjukkan dengan adanya peningkatan hasil belajar menulis dan ketuntasan indikator terhadap hasil belajar peserta didik.

Penelitian dilakukan dalam dalam dua siklus. Pada siklus I hasil tes belajar peserta didik mengalami peningkatan dari sebelumnya yaitu dengan nilai rata-rata kelas 74,88 dengan ketuntasan belajar klasikal $76,92 \%$. Walaupun terdapat peningkatan tetapi masih ada 3 peserta didik yang mendapatkan nilai dibawah KKM yaitu 70. Sehingga diperlukan adanya siklus II. Siklus II dilaksanakan berdasarkan hasil refleksi dari siklus I. Usaha perbaikan yang dilakukan pada siklus II mendapat hasil yang baik,terlihat dari hasil belajar siswa yang mengalami peningkatan yaitu nilai rata-rata kelas yang semula 74,88 meningkat menjadi 87,07. Sedangkan untuk ketuntasan belajar klasikal juga meningkat yang semula $76,92 \%$ menjadi $100 \%$. Peningkatan hasil belajar dapat dilihat pada gambar 3 . 


\section{Hasil belajar Ketrampilan Menulis Peserta didik \\ Siklus I dan II}

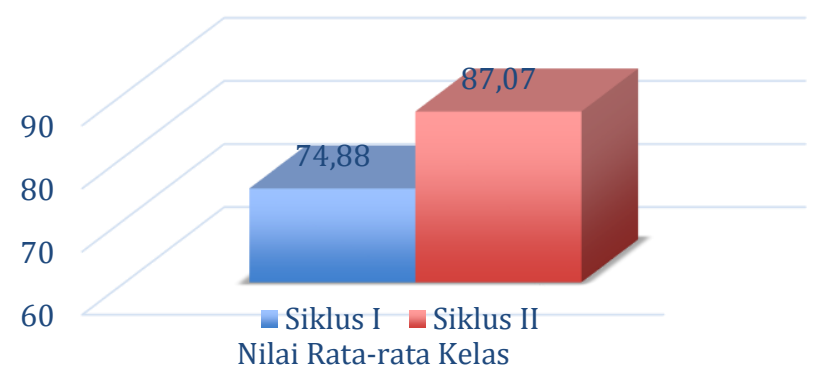

Gambar 3. Perbandingan Hasil Belajar ketrampilan Menulis siklus I dan II

\section{Implikasi Hasil Penelitian}

Berdasarkan temuan permasalahan pada pembelajaran ketrampilan menulis peserta didik materi teks fiksi dan nonfiksi pada kelas V di SDN 05 Bantarbolang Pemalang, maka penggunaan pengalaman menulis buku catatan harian dapat menarik minat peserta didik dalam menulis karangan fiksi maupun nonfiksi. Dalam hai ini, pengalaman menulis buku catatan harian digunakan sebagai sarana untuk meningkatkan hasil belajar ketrampilan menulis peserta didik.

\section{SIMPULAN}

Berdasarkan hasil penelitian tindakan kelas yang dilakukan, dapat disimpulkan bahwa penggunaan pengalaman menulis buku catatan harian dapat meningkatkan hasil belajar ketrampilan menulis peserta didik pada kelas VI di SDN 05 Bantarbolang tahun pelajaran 2019/2020. Hal ini dibuktikan dengan :

(1) Meningkatnya nilai rata-rata kelas dari 74,88 pada siklus I menjadi 87,07 pada siklus II. Selain itu, juga meningkatnya ketuntasan belajar klasikal dari $76,92 \%$ menjadi $100 \%$

(2) Penggunaan pengalaman menulis buku catatan harian yang digunakan secara berkelangsungan dapat meningkatkan ketrampilan menulis peserta didik dan dapat menarik minat peserta didik untuk menulis.

Berdasarkan simpulan maka untuk memperbaiki pembelajaran menulis dengan pengalaman menulis buku catatan harian, diperlukan saran antara lain:

(1) Bagi peserta didik diharapkan sering berlatih menulis dengan memanfaatkan buku catatan harian agar mudah menyelesaikan tugas-tugas tertulis yang diberikan guru khususnya menulis karangan.

(2) Bagi Guru dapat memanfaatkan pengalaman menulis buku catatan harian dalam pembelajaran menulis. Guru diharapkan dapat meningkatkan kualitas pembelajaran dan memotivasi siswa untuk terus melatih keterampilan menulis siswa.

(3) Bagi sekolah khususnya kepala sekolah diharapkan dapat memberikan dukungan dan kesempatan kepada guru untuk menerapkan penggunaan pengalaman menulis buku catatan harian dalam pembelajaran keterampilan menulis. Hal ini dilakukan untuk meningkatkan mutu pendidikan di sekolah dan mengoptimalkan pembelajaran menulis peserta didik 


\section{DAFTAR PUSTAKA}

Aqib, Zainal, dkk. 2010. Penelitian Tindakan Kelas untuk Guru SD, SLB, dan TK. Bandung: Yrama Widya.

Badan Standar Nasional Pendidikan. 2006. Standar Isi untuk Satuan Pendidikan Dasar dan Menengah. Jakarta: Depdiknas.

Har, Aveus. 2011. Yuk, Menulis!: Diary, Puisi, \& Cerita Fiksi. Yogyakarta: G-media

Karlina, Dety Amelia. 2011. Pengaruh Pembelajaran Menulis dengan Menggunakan Buku Catatan Harian terhadap Kebiasaan Menulis dan KeterampilanMenulis Siswa di Sekolah Dasar. Tesis Universitas Pendidikan Indonesia. Online. Available at http://repository.upi.edu/tesisview.php?no_tesis=1350 [accsessed 20/02/20].

Kristiantari, Rini. 2014. Pembelajaran Menulis di Sekolah Dasar: Menulis Deskripsi dan Narasi. Sidoarjo: Media IImu.

Kunandar. 2011. Langkah Mudah Penelitian Tindakan Kelas sebagai Pengembangan Profesi Guru. Jakarta: PT. Raj Grafindo Persada

Republik Indonesia. 2003. Undang Undang Republik Indonesia Nomor 20 Tahun 2003 Tentang Sistem Pendidikan Nasional. Jakarta : Depdiknas

Subana, M. dan Sunarti. 2011. Strategi Belajar Mengajar Bahasa Indonesia Berbagai Pendekatan, Metode Teknik, dan Media Pengajaran. Bandung: Pustaka Setia.

Sudjana, Nana. 2010. Penilaian Hasil Proses Belajar Mengajar. Bandung: PT Remaja Rosdakarya

Tarigan, Henry Guntur. 2015. Menulis sebagai Suatu Keterampilan Berbahasa. Bandung: Angkasa 